\title{
Показники гемодинаміки при артропластиці кульшового суглоба в умовах різних методів знеболювання
}

\author{
В. І. Коломаченко
}

Харківська медична академія післядипломної освіти

\section{Indices of hemodynamics in arthroplasty of the hip joint in conditions of various methods of anesthesia}

\author{
V. I. Kolomachenko \\ Kharkiv Medical Academy of Postgraduate Education
}

\section{Реферат}

Мета. Порівняння гемодинамічних профілів пацієнтів при артропластиці кульшового суглоба (КС) в умовах різних методів знеболювання.

Матеріали і методи. У 132 пацієнтів у ході виконання артропластики КС оцінювали показники гемодинаміки в періопераційному періоді в залежності від методики інтраопераційної анестезії та післяопераційної аналгезії.

Результати. На тлі спінальної анестезії спостерігали суттєве зниження артеріального тиску (АТ) з тенденцією до брадикардії, що потребувало вазопресорної підтримки. Загальна анестезія супроводжувалась досить стабільним рівнем АТ з епізодами тахікардії. Найбільш стабільною була гемодинаміка на тлі паравертебральної і каудальної епідуральної анестезії та блокад нервів (поперекового сплетення та сідничного нерва). В післяопераційному періоді гемодинаміка була найбільш стабільною на тлі пролонгованих регіональних методів аналгезії.

Висновки. Пролонговані паравертебральні блоки є оптимальним варіантом знеболювання при артропластиці КС 3 точки зору забезпечення гемодинамічної стабільності.

Ключові слова: артропластика кульшового суглоба; гемодинаміка; аналгезія; анестезія

\section{Abstract}

Objective. Comparison of hemodynamical profiles in patients during the hip joint $(\mathrm{HJ})$ arthroplasty procedure in conditions of different methods of anesthesia.

Materials and methods. In 132 patients during conduction of the $\mathrm{HJ}$ arthroplasty the perioperative hemodynamical indices, depending on the procedures of intraoperative anesthesia and postoperative anesthesia used, were estimated.

Results. Essential lowering of arterial pressure (AP) wth tendency towards bradicardia, demanding vasopressor's support, were observed on background of spinal anesthesia. General anesthesia was accompanied by a certainly stable level of AP with episodes of tachycardia. Most stable hemodynamics was observed on background of paravertebral and caudal epidural anesthesia and blockade of the nerves of a lumbar plexus and $\mathrm{n}$. ischiadicus. In postoperative period the hemodynamics was most stable on background of prolonged regional methods of anesthesia.

Conclusion. Prolonged paravertebral blocks constitute the optimal variant of anesthesia while performing the $\mathrm{HJ}$ arthroplasty in aspect of the hemodynamical stability guaranteeing.

Keywords: arthroplasty of the hip joint; hemodynamics, analgesia; anesthesia.

Пацієнти, які потребують повної артропластики КС, є складними з анестезіологічної точки зору, що зумовлено їх віком, тривалим вживанням різноманітних ліків та супутніми захворюваннями, такими як гіпертонічна хвороба, цукровий діабет, метаболічні розлади, ішемічна хвороба серця, що призводять до гемодинамічної нестабільності в періопераційному періоді. Таким чином, хірургічне втручання з приводу артропластики часто має високий ризик, а пацієнтам, яким показана така операція, загрожують смертність та післяопераційна інвалідність. Статистичні дані невтішні: приблизно 5\% пацієнтів помирають під час госпіталізації та 10\% - протягом 30 днів через тяжкі легеневі та серцево-судинні ускладнення [1 - 3]. Тому слід рішуче вживати попереджувальних заходів, щоб знизити ризик для цих хворих, та вибирати анестезію, потенційно оптимізовану для кожного пацієнта. Для загальної анестезії в залежності від обраного анестетика характерні не тільки легка або помірна гемодинамічна нестабільність, а й сумнівний контроль болю [4]. Нейраксіальним блокам (епідуральний/спінальний) також притаманні неминучі гемодинамічні зміни через симпатичний блок та непередбачуваний рівень блокади. Паравертебральну блокаду та блокаду поперекового сплетення заднім доступом використовують як методи анестезії та аналгезії в хірургії КС лише останнім часом, однак нерегулярно та обмежено через брак досвіду та інформації про ускладнення $[5,6]$. Проте саме блокади периферичних нервів можуть бути безпечними для пацієнтів із захворюваннями серцево-судинної системи за рахунок односторонньої симпатичної блокади та збереження гемодинамічної стабільності. До того ж у даний час регіональна аналгезія є більш ефективною для боротьби з болем, ніж внутрішньовенна контрольована пацієнтом аналгезія, що позитивно впливає на показники гемодинаміки в післяопераційному періоді [7]. Даних щодо порівняння гемодинамічних профілів пацієнтів у разі використання центральних та пери- 
феричних блокад для протезування КС у доступній літературі нами не знайдено.

Мета дослідження: порівняти гемодинамічні профілі пацієнтів під час виконання артропластики КС в умовах різних видів знеболювання.

\section{Матеріали і методи дослідження}

Дослідження проведене на базі Харківської обласної клінічної травматологічної лікарні щодо 132 пацієнтів, яким у 2014 - 2016 рр. у плановому порядку було виконано первинну артропластику КС. Фізичний статус пацієнтів за класифікацією ASA (Американської спілки анестезіологів) оцінений як клас II - III. Інформована згода на участь у дослідженні отримана від усіх пацієнтів до його проведення. На проведення дослідження отримано дозвіл етичного комітету Академії (протокол №5 від 23.05.2013 р.). Пацієнтів випадковим чином розподілили на шість груп (по 22 в кожній групі) в залежності від виду інтраопераційної анестезії та післяопераційної аналгезії. У 1-й групі пацієнтам виконували спінальну анестезію на рівні L3, L4 голкою G26 парамедіанним доступом у положенні лежачи на здоровому боці з уведенням 12 мг (2,4 мл) 0,5\% розчину бупівакаїну; після операції опіоїди вводили внутрішньом'язово. Пацієнтам 2-ї групи після виконання аналогічної спінальної анестезії проводили катетеризацію паравертебрального простору із застосуванням набору Perifix 401 ("BBraun", Німеччина) на рівні L3 на оперованій стороні з уведенням 20 мл 1\% розчину лідокаїну; у післяопераційному періоді в катетер вводили 0,25\% розчин бупівакаїну в $1-ш у$ добу в темпі 3 мл/год, в наступні 3 - 4 доби - по 10 мл тричі за добу. Пацієнтам 3-ї групи виконували спінально-епідуральну анестезію на рівні L3: операцію виконували під спінальною анестезією, а в післяопераційному періоді в епідуральний катетер вводили 0,125\% розчин бупівакаїну в $1-ш у$ добу в темпі 3 мл/год, в наступні 3 - 4 доби - по 10 мл тричі за добу. В 4-й групі пацієнтам виконували одноразову блокаду поперекового сплетення заднім доступом за Capdevila в комбінації 3 блокадою сідничного нерва за Labat-Moore 1\% розчином лідокаїну у дозі 800 мг з додаванням адреналіну 1:200000 та дексаметазону 4 мг; після операції опіоїди вводили внутрішньом'язово. У 5-й групі пацієнтам виконували блокаду поперекового сплетення заднім доступом за Capdevila 3 наступною катетеризацією псоас-компартменту в комбінації з каудальною блокадою, для чого використовували 20 мл 0,75\% розчину ропівакаїну; одразу після операції в катетер вводили 0,25\% розчин бупівакаїну в 1-шу до- бу в темпі 3 мл/год, в наступні 3 - 4 доби - по 10 мл тричі за добу. Пацієнтам 6-ї групи проводили загальну анестезію пропофолом за цільовою концентрацією з фентанілом та атракуріумом у загальноприйнятих дозах з інтубацією трахеї та штучною вентиляцією легенів; після операції опіоїди вводили внутрішньом'язово. У всіх пацієнтів як компоненти мультимодальної аналгезії застосовували парацетамол, нестероїдний протизапальний засіб, інфільтрацію шкіри та параартикулярних тканин місцевим анестетиком низької концентрації. За демографічними показниками та тривалістю операцій групи статистично значущо не відрізнялись.

Показники гемодинаміки оцінювали за допомогою приліжкового монітору PVM-2701 (фірма «Nihon Kohden», Японія) на шести етапах: перед анестезією (1-й етап), після виконання блокад або інтубації трахеї (2-й етап), на початку операції (3-й етап), під час травматичного етапу операції (4-й етап), наприкінці операції (5-й етап) і на ранок наступного дня (6-й етап). Визначали частоту серцевих скорочень (ЧСС), систолічний артеріальний тиск (САТ), діастолічний артеріальний тиск (ДАТ), середньОдинамічний артеріальний тиск (СДАТ).

Математичне опрацювання отриманих результатів здійснювали за допомогою програм Excel фірми Microsoft. Статистичну значущість змін показників у групі оцінювали спарованим двобічним критерієм Ст’юдента, значущість міжгрупової різниці - неспарованим двобічним критерієм Ст'юдента, за рівень достовірності різниці вважали $\mathrm{p}<0,05$. Результати наведені у вигляді: середнє значення \pm стандартне відхилення $(\mathrm{M} \pm \sigma)$.

\section{Результати}

Перед операцією показники ЧСС ( мабл. 1) перебували в межах нормальних значень з тенденцією до підвищення, що можна пояснити хвилюванням хворих перед втручанням, незважаючи на премедикацію бензодіазепінами. Після виконання регіональних блоків у хворих 1-3-ї та 5-ї груп відбувалося клінічно суттєве та статистично значуще зниження ЧСС на всіх етапах дослідження порівняно з вихідними показниками. Причому ЧСС суттєво знижувалась на 2-му та 3-му етапах, а на наступних етапах зберігалась на однаковому рівні. Найбільш стабільними показники ЧСС були у паціентів 4-ї групи, тенденцію до брадикардії спостерігали лише наприкінці операції ( $\mathrm{p}=0,019)$. Навіть на травматичному етапі показники ЧСС у цих пацієнтів залишалися стабільними, що свідчить про адекватний антиноцицептивний захист. Показники ЧСС у паці-

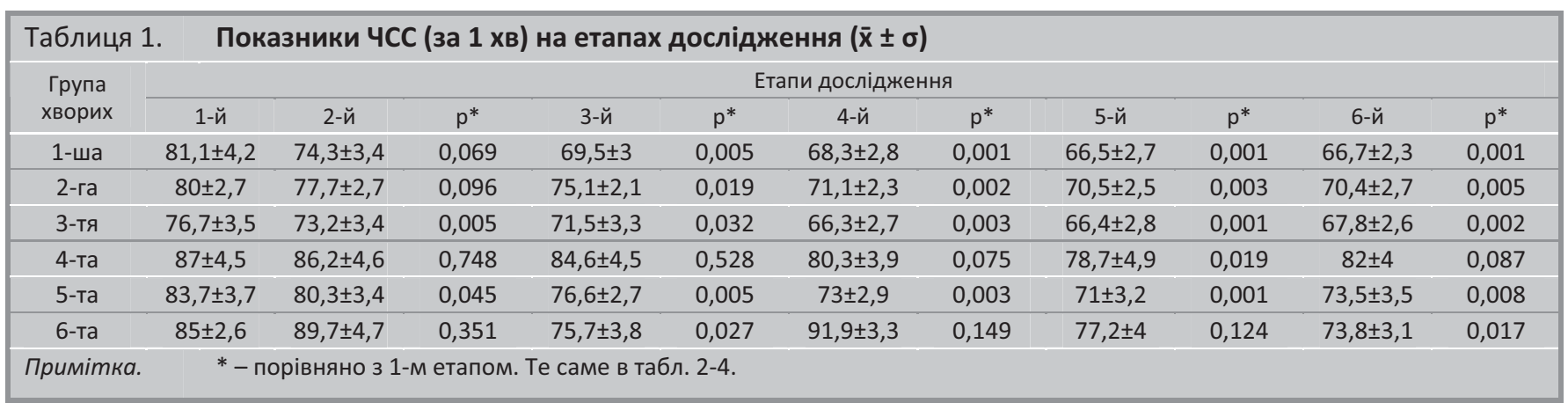




\begin{tabular}{|c|c|c|c|c|c|c|c|c|c|c|c|}
\hline \multirow{2}{*}{$\begin{array}{l}\text { Група } \\
\text { хворих }\end{array}$} & \multicolumn{11}{|c|}{ Етапи дослідження } \\
\hline & 1-й & $2-и ̆$ & $p^{*}$ & $3-и ̆$ & $p^{*}$ & 4-й & $p^{*}$ & 5-й & $p^{*}$ & 6-й & $p^{*}$ \\
\hline 1-ша & $158,4 \pm 5,5$ & $130,4 \pm 5,1$ & 0,001 & $121,4 \pm 3,9$ & 0,001 & $122,9 \pm 5,5$ & 0,001 & $120,2 \pm 3,6$ & 0,001 & $131,8 \pm 4,4$ & 0,001 \\
\hline 2-га & $159,1 \pm 4,7$ & $133,7 \pm 4,6$ & 0,001 & $125,6 \pm 4,8$ & 0,001 & $123,7 \pm 4,8$ & 0,001 & $127 \pm 5,5$ & 0,001 & $137,4 \pm 3,3$ & 0,001 \\
\hline 3-тя & $156 \pm 5,4$ & $129,2 \pm 3,9$ & 0,002 & $121,9 \pm 5,2$ & 0,001 & $129,5 \pm 4,5$ & 0,001 & $131,5 \pm 4,1$ & 0,001 & $130,5 \pm 5,5$ & 0,001 \\
\hline 4-та & $142,3 \pm 5,9$ & $143,5 \pm 7,2$ & 0,787 & $136,7 \pm 5,8$ & 0,238 & $142,3 \pm 6,5$ & 1,000 & $134,7 \pm 5,6$ & 0,203 & $138,5 \pm 5,1$ & 0,617 \\
\hline 5-та & $150,8 \pm 4,4$ & $139,9 \pm 4,5$ & 0,036 & $131,9 \pm 4,6$ & 0,001 & $135,5 \pm 4,6$ & 0,004 & $135,1 \pm 5$ & 0,008 & $136 \pm 3,4$ & 0,003 \\
\hline 6-та & $148,8 \pm 6,4$ & $123,3 \pm 9,1$ & 0,019 & $122,8 \pm 4,6$ & 0,001 & $128 \pm 5,7$ & 0,023 & $130,5 \pm 4,5$ & 0,038 & $126,5 \pm 3,6$ & 0,013 \\
\hline
\end{tabular}

Таблиця 3. Показники ДАТ (мм рт.ст.) на етапах дослідження ( $\overline{\mathbf{x}} \pm \sigma)$

\begin{tabular}{|c|c|c|c|c|c|c|c|c|c|c|c|}
\hline \multirow{2}{*}{$\begin{array}{l}\text { Група } \\
\text { хворих }\end{array}$} & \multicolumn{11}{|c|}{ Етапи дослідження } \\
\hline & 1-й & $2-и ̆$ & $\mathrm{p}^{*}$ & $3-и ̆$ & $\mathrm{p}^{*}$ & $4-и ̆$ & $\mathrm{p}^{*}$ & $5-и ̆$ & $p^{*}$ & 6-й & $p^{*}$ \\
\hline 1-ша & $87 \pm 3,6$ & $70,6 \pm 3,8$ & 0,001 & $67 \pm 4,9$ & 0,001 & $64,9 \pm 4,5$ & 0,001 & $66,6 \pm 3,3$ & 0,001 & $72,7 \pm 3$ & 0,003 \\
\hline 2-га & $82 \pm 4$ & $73,4 \pm 4,1$ & 0,008 & $67,6 \pm 3,4$ & 0,001 & $66 \pm 3,4$ & 0,001 & $66,5 \pm 3,7$ & 0,001 & $71,6 \pm 3,3$ & 0,001 \\
\hline 3-тя & $81,7 \pm 4,1$ & $67,9 \pm 3,6$ & 0,001 & $66,3 \pm 3,7$ & 0,001 & $68,1 \pm 3,1$ & 0,004 & $68,1 \pm 2,8$ & 0,001 & $68,9 \pm 3,6$ & 0,003 \\
\hline 4-та & $84,3 \pm 3,6$ & $84,3 \pm 3,3$ & 1,0 & $83,1 \pm 5,4$ & 0,733 & $89 \pm 5$ & 0,251 & $86,1 \pm 5$ & 0,712 & $87,7 \pm 5,2$ & 0,512 \\
\hline 5-та & $85,1 \pm 4,3$ & $78,9 \pm 4,2$ & 0,039 & $77,7 \pm 3,5$ & 0,014 & $73,5 \pm 3,1$ & 0,006 & $78,9 \pm 4,1$ & 0,144 & $78,8 \pm 3,5$ & 0,024 \\
\hline 6-та & $93,9 \pm 4,2$ & $80,9 \pm 5,1$ & 0,022 & $80,1 \pm 3,7$ & 0,006 & $83,9 \pm 3,7$ & 0,089 & $85,6 \pm 3,8$ & 0,144 & $82,4 \pm 2,8$ & 0,027 \\
\hline
\end{tabular}

єнтів 6-ї групи також коливалися несуттєво, але це єдина група, в якій ми спостерігали тахікардію на травматично-

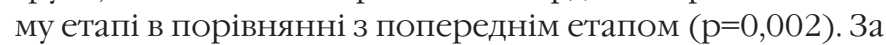
рахунок тенденції ЧСС до брадикардії у пацієнтів 1 - 3-ї груп та стабільності ЧСС у пацієнтів 4-ї групи ми констатували статистично значущу різницю між ними на всіх етапах. Подібні зміни ЧСС, але білыш суттеві за рахунок тенденції до тахікардії, отримані у пацієнтів 6-ї групи порівняно з пацієнтами решти груп, особливо оперованих в умовах нейраксіальних блокад. На травматичному етапі за показниками ЧСС пацієнти 6-ї групи статистично значущо відрізнялися від пацієнтів решти груп, що свідчить про недостатній антиноцицептивний захист загальної анестезії для такої травматичної операції. Показники ЧСС у пацієнтів 4-ї та 5-ї груп на всіх етапах не відрізнялися, що свідчить про менші зрушення ЧСС у разі застосування каудальної блокади.

Показники САТ (табл. 2) на 1-му етапі у всіх пацієнтів були дещо підвищені, що зумовлено насамперед віком хворих та наявною у більшості з них гіпертонічною хворобою, а також емоційною складовою.

У пацієнтів 4-ї групи коливання САТ на всіх етапах спостереження були мінімальними. У пацієнтів решти груп САТ порівняно з вихідними значеннями досить різко знижувався відразу після виконання блокади або інтубації і зберігався на такому рівні протягом усіх подальших етапів спостереження. За рахунок зниження САТ у пацієнтів, яким виконували нейраксіальні блокади, та стабільності цього показника у пацієнтів, яким виконували блокаду нервів, ми спостерігали статистично значущу різницю між ними від початку і до кінця операції. У пацієнтів 5-ї групи показники САТ були більш стабільними в порівнянні з показниками у пацієнтів решти груп, яким виконували центральні блокади, але статистично значущу різницю між ними і показниками у пацієнтів однієї 1-ї групи спостерігали лише наприкінці операції.
Показники ДАТ ( мабл.3) не відрізнялися у всіх пацієнтів на 1-му етапі, але на наступних етапах різниця між ними була суттєвою у пацієнтів різних груп. Найбілыш суттєво показники ДАТ знизилися в 1 - 3-й групах відразу після виконання блокади і статистично значущо (р < 0,001) відрізнялися практично на всіх етапах від вихідних значень. Подібно змінювалися показники ДАТ у 5-й та 6-й групах, але менш суттєво, тобто вони змінювалися повільніше, а їх стабілізація відбувалася швидше. У пацієнтів 4-ї групи показники ДАТ протягом періоду спостереження залишалися стабільними, не демонструючи статистично значущих змін. За рахунок різкого зниження показників ДАТ у 1 - 3-й групах та їх стабільності у пацієнтів 4-ї групи спостерігали статистично значущу різницю між групами протягом усього дослідження. 3 3-го етапу дослідження статистично значущо відрізнялися показники ДАТ у пацієнтів, оперованих в умовах спінальної та загальної анестезії. Після виконання центральних нейраксіальних блокад мінімальні зміни ДАТ спостерігали у пацієнтів, оперованих в умовах каудальної блокади, про що свідчила статистично значуща різниця між ними на 3-му, 4-му та 5-му етапах.

Коливання СДАТ ( мабл.4) корелювали зі змінами САТ та ДАТ у групах. Спостерігали різке та тривале зниження показників СДАТ у пацієнтів, оперованих в умовах центральних нейраксіальних блокад розпочинаючи з другого етапу, найбільш повільне та найменш виражене - у пацієнтів, оперованих в умовах каудальної блокади. У пацієнтів, оперованих в умовах загальної анестезіі, зниження показників СДАТ також було статистично значущим, але клінічно менш суттєвим. Найбільш стабільними показники СДАТ були після виконання блоків нервів. За рахунок суттєвих коливань показники СДАТ у пацієнтів, оперованих в умовах спінальної анестезії, статистично значущо відрізнялися від аналогічних показників у пацієнтів решти груп на різних етапах. Найбільш наочно це видно, 


\begin{tabular}{|c|c|c|c|c|c|c|c|c|c|c|c|}
\hline \multirow{2}{*}{$\begin{array}{c}\text { Група } \\
\text { хворих }\end{array}$} & \multicolumn{11}{|c|}{ Етапи дослідження } \\
\hline & $1-и ̆$ & $2-и ̆$ & $\mathrm{p}^{*}$ & $3-и ̆$ & $p^{*}$ & 4-й & $\mathrm{p}^{*}$ & 5-й & $\mathrm{p}^{*}$ & 6-й & $p^{*}$ \\
\hline 1-ша & $110,3 \pm 5,2$ & $92,2 \pm 4,5$ & 0,001 & $82,3 \pm 4,6$ & 0,001 & $79,5 \pm 4,7$ & 0,001 & $81,1 \pm 3$ & 0,001 & $91,3 \pm 3,7$ & 0,002 \\
\hline 2-га & $106,9 \pm 4,3$ & $89,5 \pm 4,5$ & 0,001 & $88 \pm 4,4$ & 0,001 & $84 \pm 3,9$ & 0,001 & $83 \pm 4,1$ & 0,001 & $92,1 \pm 4,4$ & 0,001 \\
\hline 3-тя & $105,5 \pm 5,2$ & $84,9 \pm 4,1$ & 0,001 & $86,3 \pm 3,9$ & 0,001 & $87,1 \pm 3$ & 0,007 & $89,1 \pm 2,4$ & 0,002 & $90,7 \pm 4,7$ & 0,002 \\
\hline 4-та & $100,9 \pm 5,4$ & $99,3 \pm 4,7$ & 0,603 & $98,1 \pm 5,9$ & 0,484 & $104,5 \pm 5,7$ & 0,523 & $97,1 \pm 5,3$ & 0,493 & $100,3 \pm 5,1$ & 0,927 \\
\hline 5-та & $106,3 \pm 4,6$ & $94 \pm 4,4$ & 0,015 & $95,6 \pm 4,4$ & 0,004 & $88,3 \pm 3,8$ & 0,005 & $92,2 \pm 3,7$ & 0,010 & $96,9 \pm 3,3$ & 0,026 \\
\hline 6-та & $110,7 \pm 5,8$ & $92,3 \pm 5,7$ & 0,011 & $93,3 \pm 3,9$ & 0,006 & $95,7 \pm 4,2$ & 0,038 & $99,1 \pm 3,7$ & 0,136 & $95,5 \pm 3,5$ & 0,039 \\
\hline
\end{tabular}

коли порівняти показники СДАТ у пацієнтів, оперованих в умовах спінальної анестезіі, і у пацієнтів, оперованих в умовах блоків нервів. Після виконання центральних нейраксіальних блокад найменші зміни СДАТ були у пацієнтів 4-ї групи, оперованих в умовах каудальної анестезії в поєднанні з паравертебральним блоком.

\section{Обговорення}

Серцево-легеневі ускладнення, навіть якщо не враховувати емболію легеневої артерії, є найбільш частою причиною смерті пацієнтів після повної артропластики суглобів [8]. Частота виконання артропластики КС за останні десятиліття постійно зростає, що спонукає до створення нових та удосконалення існуючих методів анестезії та аналгезії з метою отримання найкращих результатів. Сьогодні лікарі використовують різні методи знеболювання, дедалі частіше обираючи регіональні, що зумовлено низкою переваг, пов'язаних не безпосередньо зі знеболюванням, а таких як зниження смертності, зменшення об'єму крововтрати, частоти тромбоемболічних, серцево-легеневих ускладнень, інфекцій і сприятливі економічні результати [9]. Проте рішення про використання регіональної анестезії треба приймати з обережністю за наявності, зокрема, супутніх серцево-судинних захворювань, оскільки деякі з них суттєво впливають на гемодинаміку.

Центральні нейраксіальні блоки, особливо спінальний, приводять до швидкої та глибокої вазодилатації, що викликає зниження АТ та ЧСС. Це підтверджено не тільки отриманими нами результатами, а й даними V. A. Tummala і співавторів, які спостерігали гіпотонію та брадикардію у 66,7 та 30\% хворих відповідно, яким в умовах спінальної анестезії виконували ендопротезування КС. Тому у більше як половини хворих доводилося вдаватися до повторного введення симпатоміметиків (ефедрин 6 мг) для підтримання показників САТ на бажаному рівні [10]. Різкі коливання гемодинаміки можуть негативно позначитися на доставці кисню до міокарда та викликати його ішемію. Дослідники, які вивчали гемодинаміку і маркери ішемії міокарда у пацієнтів з ішемічною хворобою серця, оперованих $з$ приводу перелому стегна, отримали дані, що епізоди депресії сегмента ST виникали у пацієнтів незалежно від методу анестезії (спінальна чи загальна), але їх частота у пацієнтів, що мали гіпотензію, становила 56\%, а у пацієнтів, що не мали гіпотензії, лише 10\% [11]. Зважаючи на це, більш привабливим є застосування у даної категорії хворих епідуральної, зокрема, сакральної анестезії в комбінації з блокадою гілок поперекового сплетення, що за- безпечує надійну анестезію з меншими гемодинамічними коливаннями. Це продемонстрували результати і нашого дослідження. За гемодинамічним профілем такі пацієнти майже не відрізнялися статистично значущо від найбільш гемодинамічно стабільних пацієнтів, оперованих в умовах периферичних блокад нервів. Винятком було лише достовірно більше зниження показників ДАТ на 4-му етапі, що можна пояснити суттєвішим зниженням загального периферичного судинного опору у разі виконання епідуральної блокади.

Блоки периферичних нервів нижніх кінцівок супроводжувались мінімальними гемодинамічними порушеннями, що зумовлено обмеженою зоною симпатектомії та узгоджується з результатами інших досліджень. G. Fanelli і співавтори порівняли гемодинамічні зміни, викликані односторонньою спінальною анестезією і комбінованим блоком стегнового та сідничного нервів. Пацієнти обох груп мали адекватну анестезію для операціі. Блоки нервів (7 мг/кг 2\% розчину мепівакаїну) не призводили до значних змін гемодинаміки, тоді як у пацієнтів, оперованих в умовах спінальної анестезії (8 мг гіпербаричного 0,5\% розчину бупівакаїну), істотно знижувалися показники САТ, серцевого та ударного індексів [12].

Підтверджує результати нашого дослідження щодо гемодинамічної стабільності пацієнтів, оперованих на нижніх кінцівках на фоні блоків нервів, широке та успішне використання останніх у пацієнтів високого ризику в усьому світі. А. М. Но і співавтори повідомили про використання комбінованої анестезії поперекового сплетення та парасакрального блоку сідничного нерва для операції на стегні у пацієнта похилого віку з тяжким аортальним стенозом [13]. Y. Tanaka i T. Negoro описали використання псоас-компартмент блоку для виконання операції з приводу перелому стегна у 72-літньої хворої, яка мала тяжку серцеву недостатність через ревматоїдний міокардит [14]. N. Chia і співавтори спостерігали практичну перевагу комбінованого блоку сідничного та стегнового нервів у 56-річного пацієнта з тяжким сепсисом і недавнім інфарктом міокарда, якому вони виконали термінову ампутацію вище коліна [15]. D. Rizzo і співавтори використовували регіональні техніки анестезіі для виконання артроскопії колінного суглоба у 32-річного пацієнта із синдромом Ейзенменгера [16].

Численні регіональні методики не лише здатні забезпечити якісну аналгезію, а й відіграють суттєву роль в лікуванні пацієнтів з супутніми серцево-судинними захворюваннями. Проте потрібно пам'ятати, що використову- 
вати центральні нейраксіальні блокади потрібно обережно, оскільки раптове або надмірне зниження периферичного судинного опору може прискорити зниження перфузії міокарда i/або зниження переднавантаження і серцевого викиду з тяжкими наслідками. У цих пацієнтів застосування регіональної анестезії, крім обережності, потребує ще й відповідного контролю. Тому лікар, застосовуючи методику, повинен враховувати не тільки характер операції, а й сукупність проблем зі здоров'ям, які має кожен окремий пацієнт.

Отже, узагальнені результати нашого дослідження є такими: на тлі спінальної анестезії суттєво знижувався АТ 3 тенденцією до брадикардії, що потребувало вазопресорної підтримки; загальна анестезія супроводжувалась досить стабільним рівнем АТ, але з епізодами тахікардії; найбільш стабільною була гемодинаміка на тлі паравертебральної і каудальної епідуральної анестезії та блокад нервів (поперекового сплетення та сідничного нерва); в післяопераційному періоді гемодинаміка була найбільш стабільною на тлі пролонгованих регіональних методів аналгезії.

\section{Висновки}

1. Пролонговані паравертебральні блоки є оптимальним варіантом знеболювання для артропластики КС 3 точки зору забезпечення гемодинамічної стабільності.

2. У подальшій перспективі потрібно дослідити вплив різних препаратів для регіонального знеболювання у даної категорії пацієнтів.

\section{References}

1. Lawrence VA, Hilsenbeck SG, Noveck H, Poses RM, Carson JL. Medical complications and outcomes after hip fracture repair. Arch Intern Med. 2002 Oct 14;162(18):2053-7. PMID: 12374513. doi:10.1001/ archinte.162.18.2053.

2. Roche JJW, Wenn RT, Sahota O, Moran CG. Effect of comorbidities and postoperative complications on mortality after hip fracture in elderly people: Prospective Observational Cohort Study. BMJ. 2005;331:1374-6. doi:10.1136/bmj.38643.663843.55.

3. Radcliff TA, Henderson WG, Stoner TJ, Khuri SF, Dohm M, Hutt E. Patient risk factors, operative care, and outcomes among older community-dwelling male veterans with hip fracture. Journal of Bone and Joint Surgery. 2008;90(1):34-42. doi: 10.2106/JBJS.G.00065.

4. Movasseghi G, Hassani V, Mohaghegh MR, Safaeian R, Safari S, Zamani MM, Nabizadeh R. Comparison between spinal and general anesthesia in percutaneous nephrolithotomy. Anesth. Pain Med. 2013;4(1): e13871. doi: $10.5812 /$ aapm. 13871

5. Amiri HR, Safari S, Makarem J, Rahimi M, Jahanshahi B. Comparison of combined femoral nerve block and spinal anesthesia with lumbar plexus block for postoperative analgesia in intertrochanteric fracture surgery. Anesth Pain Med. 2012;2(2):32-5. doi: 10.5812/aapm.4526.

6. Moghtadaei M, Farahini H, Faiz SH-R, Mokarami F, Safari S. Pain Management for Total Knee Arthroplasty: Single-Injection Femoral Nerve Block versus Local Infiltration Analgesia. Iran Red Cres Med J. 2014 Jan;16(1):e13247. doi: 10.5812/ircmj.13247.

7. Becchi C, Al Malyan M, Coppini R, Campolo M, Magherini M, Boncinelli S. Opioid-free analgesia by continuous psoas compartment block after total hip arthroplasty. A randomized study. Eur J Anaesthesiol. 2008;25:418-23. doi: 10.1017/S026502150700302X

8. Poultsides LA, Gonzalez DVA, Memtsoudis SG, Ma Y, Roberts T, Sharrock N, Salvati E. Meta-analysis of cause of death following total joint replacement using different thromboprophylaxis regimens. J Bone Joint Surg Br. 2012 Jan;94(1):113-21. doi: 10.1302/0301-620X.94B1.27301.

9. Stein BE, Srikumaran U, Tan EW, Freehill MT, Wilckens JH. Lower-extremity peripheral nerve blocks in the perioperative pain management of orthopaedic patients: AAOS exhibit selection. J Bone Joint Surg Am. 2012;94(22):e167. doi: 10.2106/JBJS.K.01706.

10. Tummala VA, Rao LN, Vallury MK, Sanapala A. A comparative study-efficacy and safety of combined spinal epidural anesthesia versus spinal anesthesia in high-risk geriatric patients for surgeries around the hip joint. Anesth Essays Res. 2015 May-Aug;9(2):185-8. doi: 10.4103/0259-1162.153764. PMID: 26417125 PMCID: PMC4563971.

11. Juelsgaard P, Sand NPR, Felsby S, Dalsgaard J, Jakobsen KB, Brink O, Carlsson PS, Thygesen K. Perioperative myocardial ischaemia in patients undergoing surgery for fractured hip randomized to incremental spinal, single-dose spinal or general anaesthesia. EJA. 1998;15(6):65663. doi: 10.1097/00003643-199811000-00006.

12. Fanelli G, Casati DrA, Aldegheri G, Beccaria P, Berti M, Leoni A. Cardiovascular effects of two different regional anaesthetic techniques for unilateral leg surgery. Acta Anaesthesiol Scand. 1998;42(1):80-4. doi:10.1111/j.1399-6576.1998.tb05084.x.

13. Ho AM, Karmakar MK. Combined paravertebral lumbar plexus and parasacral sciatic nerve block for reduction of hip fracture in a patient with severe aortic stenosis. Can J Anaesth. 2002;49:946-50. doi: 10.1007/ BF03016880.

14. Tanaka Y, Negoro T. Psoas compartment block for surgery of the femoral neck (trochanteric) fracture in a patient with severe heart failure due to rheumatoid myocarditis. Masui. 2000;49:1133-5. PMID:11075563.

15. Chia N, Low TC, Poon KH, Chia N. Peripheral nerve blocks for lower limb surgery - a choice anaesthetic technique for patients with a recent myocardial infarction? Singapore Med J. 2002;43:583-6. PMID: 12680529 .

16. Rizzo D, Giustiniano E, Pellicori D, Misiti CM, Cosco G. Sciatic, femoral and lateral cutaneous of thingh nerves block for arthroscopic extirpation of meniscus in a patient suffering from Eisenmerger syndrome. Case report. Minerva Anestesiol. 1999;65(10):733-6. PMID:10598431. 